\title{
Price relations between international rice markets
}

\author{
Adam John
}

\author{
Correspondence: adam.dr.john@ \\ hotmail.com \\ Institute of Agricultural and Food \\ Policy Studies, Universiti Putra \\ Malaysia, Putra Infoport, Jalan \\ Kajang-Puchong, 43400 UPM, Ser- \\ dang, Selangor, Malaysia
}

\begin{abstract}
International rice markets are seen as volatile due to the thin nature of the market which is believed to be exacerbated by a low level of substitution between major rice export markets. In other words, this perceived lack of price transmission amongst international rice markets is believed to further thin out an already thin world rice market. The paper tests for price transmission between five major rice exporting markets representing Asia and the Americas over the past decade. It uses a vector autoregressive framework and performs Granger and Toda-Yamamoto causality tests and generalized impulse response functions to interpret the model's results. The findings suggest that price transmission exists across these major rice export markets with price relations being the most widespread between Asian markets. Furthermore, the direction of price transmission suggests that Asian prices act as price leaders for North and South American prices. While it is not clear whether there is a price leader amongst the Asian export markets, Vietnam has the most extensive price relations with other export markets which would suggest that the Vietnamese rice export price is a more suitable world reference price than the Thai export price. An implication of the presence of price relations between rice export markets is that the world rice market is not as fragmented as generally perceived in the literature. However, it can also explain why international rice prices are so sensitive to the volatile trading behavior of major markets.
\end{abstract}

Keywords: Rice export markets; Price transmission; Causality tests; Impulse response functions; World reference price

\section{Background}

The world rice market is seen as a thin market which is used to explain its volatile nature (Siamwalla and Haykin, 1983; Gibson, 1994; Wailes, 2002; Nielsen, 2003; Wailes, 2005; Headey, 2011; and Rapsomanikis, 2011). Two explanations are usually given for why it is a thin market. Firstly, it has been pointed out that the proportion of world rice production traded internationally represents just seven percent of the market (Wailes, 2005; Headey, 2011). In such an event, prices do not reflect the supply and demand conditions of the market (Tomek and Robinson, 1990), it increases search costs and can lead to excessive price volatility (Anderson et al. 2007). The second argument given is that international rice markets have a low level of substitution (Petzel and Monke, 1980; Siamwalla and Haykin, 1983 Rastegari-Henneberry, 1985; Cramer et al. 1993; Jayne, 1993; Chan, 1997, Wailes, 2005; Dawe, 2008) which fragments the world market into even smaller unrelated markets and makes it harder to discover price information (Jayne, 1993).

(C) 2014 John; licensee Springer. This is an Open Access article distributed under the terms of the Creative Commons Attribution License (http://creativecommons.org/licenses/by/2.0), which permits unrestricted use, distribution, and reproduction in any medium, provided the original work is properly cited. 
Due to the latter argument, one would expect price relations between international rice markets to be weak with little price transmission taking place across different geographical rice markets. The behavior of international rice prices and trade, however, would suggest that rice markets must be related to some extent, at least in contemporary times. Firstly, the huge surge in international rice prices in 2007-2008 was felt worldwide which transmitted over to most Asian, African and Latin American domestic markets (Demeke et al. 2011). Secondly, major rice exporting nations are competing in some of the same markets, particularly in Africa and parts of Latin America ${ }^{a}$.

The aim of this study is to test to what extent international rice markets are related to each other by measuring price transmission using the monthly export rice prices of five major markets taken from FAO's Global Information and Early Warning System database. The prices are specified into a vector auto regression (VAR) model and the results are interpreted using Granger and Toda-Yamamoto causality tests as well as generalized impulse response functions (IRF). The causality tests are used to verify whether price transmission exists between several major rice export markets from Asia and the Americas. Furthermore, generalized impulse response functions are simulated to provide information on the magnitude and persistence of the price transmission which takes place between international rice markets. Understanding the extent of price relations between international rice markets gives an indication of how well the world rice market functions and even whether it is appropriate to view international rice markets as a single market. It also gives an idea of how competitive exporting countries are and since the causality tests can indicate the direction of price transmission, the testing procedure can also provide an insight into whether there are certain markets which act as price leaders.

Rice exporting nations are often reported to distort their export prices in order to stabilize their own domestic markets (Dorosh, 2009; Gilbert and Morgan, 2010; Timmer, 2010; Dawe and Slayton, 2011; Demeke, et al. 2011; Headey, 2011). Headey (2011) and Gilbert (2013) both believe such behavior played a major role in the huge price hikes seen in international rice prices and more recently, the perceived unreliability of international rice markets has led to the promotion of rice self sufficiency polices in many traditional rice importing countries under the guise of national food security (Stage and Rekve, 1998; Chand, 2006; Xiufang and Dwyer, 2008; Seck et al. 2010; Demeke et al. 2011). A problem with these policies is that they are expected to make the world rice market even thinner and therefore more volatile (Jayne (1993; Wailes, 2005). If export prices are found to be related then it would suggest that exporting nations are to some extent responsive to the market's price movements and therefore not as price distortive as perceived.

The study not only tests for the existence of price transmission between international rice markets but also the direction of price transmission. The direction is also of interest as this information can provide further insights such as whether there exists a suitable reference price for the world rice price. International organizations such as the International Monetary Fund (IMF) tend to use the Thai export FOB price as a proxy for the world rice price which is sensible since Thailand is traditionally the largest rice exporter. The estimation procedure of this study also allows for testing whether the Thai price is a suitable proxy or whether international rice prices are too isolated and fragmented for there to be a credible world rice price. 


\section{Literature review}

There are numerous varieties of rice which are consumed and traded; however, conventional indica varieties make up 85 per cent of world rice consumption and 80 per cent of world rice trade (Jayne, 1993; Dawe, 2008). The general view has been that prices of the different rice varieties, such as indica and japonica markets are unrelated (Petzel and Monke, 1980; Siamwalla and Haykin, 1983 Rastegari-Henneberry, 1985; Dawe, 2008). However, Falcon and Monke (1980) expected indica prices between Asian and American export markets to be integrated and Dawe (2008) also expected these markets were strongly related throughout the 1980s. In more contemporary times however, Dawe (2008) believes that American and Asian indica rice markets act more like two separate commodity markets which he argues can be explained by the fact that the US does not export rice to Asian markets.

Testing for price transmission under a market integration framework using cointegration tests has been a common practice in the literature. However, most studies related to rice markets have focused on testing for price transmission between international and domestic rice markets in order to assess how integrated domestic rice markets are with international markets. However, Ghoshray (2008) used this approach to test for price relations between two major rice export markets and found evidence which suggested that Thailand and Vietnam's export prices were asymmetrically cointegrated. That is to say that although their prices share a long-run relationship, price transmission is asymmetric, which is a sign of uncompetitive behavior. He found the prices to be asymmetric in the sense that price adjustments occur faster when the price differentials are in decline rather than when they are increasing. In addition, Ghoshray (2008) looked for whether there was a rice price leader between Thailand and Vietnam. He concluded that Thailand acts as a price leader for higher quality grades but also responds to Vietnamese price movements to some extent in the short-run.

Using causality tests and IRFs to interpret the results of a VAR model for assessing price transmission between Thailand's domestic and export rice markets, John (2013) found price transmission to be bi-directional. However, the magnitude and persistence of price transmission based on the IRF results between the two markets was found to vary substantially, suggesting that although Thailand's paddy pledging program distorts prices and hinders price transmission between Thai domestic and export prices in the short-run to some extent, Thai export price movements eventually transmit through to domestic prices substantially.

\section{Methods}

Research focused on measuring price transmission between spatial markets has most often been concerned with testing for market integration which uses the Law of One Price (LOP) as a theoretical framework. LOP asserts that at all points of time the relationship between two markets is as follows:

$$
p 1 t=c+p 2 t
$$

where due to instantaneous competitive arbitrage the price differential between market $p_{1}$ and market $p_{2}$ at time $t$ is the transfer cost $(c)$ of the product to each of the markets $^{\mathrm{b}}$. The notion stated in equation (1) is a strong form of market integration since markets deviating from this are considered not to be integrated and therefore no price 
transmission takes place. If this relationship holds then it is said that markets are integrated and full transmission takes place. A weaker form of LOP allows the price relationship to be as follows:

$$
|p 2 t-p 1 t| \leq c
$$

where the price differential between markets may be less than the transfer cost but efficient arbitrage will not allow the deviation to exceed the transfer cost. Equation (2) is less restrictive in the sense that transmission can take place even when the price differential is less than the transfer cost and suggests an equilibrium condition.

$$
|p 2 t-p 1 t|=c
$$

One might expect the condition in equation (3) to occur in the long run since traders would leave the market if price deviations did not cover the transfer cost. However, the condition in equation (2) can occur at least in the short run. This is essentially relaxing the assumption of instantaneous arbitrage. In terms of price transmission, this may mean that while transmission may not take place fully in the short run between integrated markets, full transmission would be expected to occur in the long run. In the context of price transmission, cointegration can be seen as the empirical equivalent of the theoretical concept of a weaker form of LOP, where it is accepted that while price transmission does not adjust instantly, in the long run the full extent of the transmission takes place. However, the traditional linear cointegration tests have been criticized because they do not consider the existence of non-stationary transfer costs. Ghoshray (2008) overcomes this criticism by using threshold autoregressive (TAR) models which allow for asymmetric error corrections in the cointegration tests.

This study adopts less restrictive estimation techniques for measuring price transmission, namely causality tests and impulse response functions. While testing for cointegration is a common procedure, the more conventional cointegration methods are rather restrictive as they require all of the price series to be I(1) non-stationary processes. Cointegration techniques have also been criticized as not being suitable tools for measuring market integration on several grounds including the fact that they do not consider the trade behavior of countries (Barrett and Li, 2002). One of the largest concerns with the LOP framework is that transfer costs between markets can be so great that it does not seem appropriate to test for market integration but instead simply test to see whether markets have in fact any price relationship. Transportation is perhaps the most obvious transfer cost which affects price transmission; however the factor which has been given the most attention in the literature, when assessing spatial markets, is border and domestic policies (Conforti, 2004). Conforti (2004) sees product homogeneity, that is to say, the level of substitutability between products across different markets, to be particularly important to world rice markets. If rice markets have a high level of differentiation, prices across markets are likely to differ substantially. Other key factors considered important to spatial price transmission are: transaction costs, exchange rates, market power, and increasing returns to scale in production (Conforti, 2004; Ghoshray, 2011; Gilbert, 2011). In this study, the aim is not to test for market integration but merely provide some insight into the competiveness of major rice export markets by testing whether their price movements are related. 


\section{Vector autoregression (VAR)}

A VAR is a system of equations which is rooted in the Box-Jenkins procedure. It presumes that the best way of predicting movements in $x$ are the past values of $x$ as well as the past values of other variables. Since no restrictions are made in the system, everything is assumed to affect everything and there are no endogeneity issues since there are no contemporaneous explanatory variables. Its simplicity makes it an attractive model as compared to the traditional structural equation models which demand sound economic theory surrounding the relationship between the studied variables. The absence of a solid theoretical background linking the variables within the VAR system has also been regarded as a critical weakness of the model which has led to the popularity of restricted VAR models. For this study, it is felt that there should be no restrictions on the relations between any of the export prices as the assumption that all of the prices affect one another is sensible if the markets are competitive. Therefore, specifying a restricted VAR would be inappropriate in this case.

The equations of the VAR are estimated using the ordinary least squares (OLS) procedure therefore all price series within the system must be stationary processes otherwise the OLS assumptions are violated. Knowledge about the stationarity of the price series is therefore required. If the prices are stationary then the price series can enter the VAR system in their level form. However, if any of the prices are non-stationary, the series will need to be first-differenced before they can enter the VAR system in order to ensure the OLS assumption of stationarity is not violated. As an example, a simple $2 \times 2$ VAR can be specified as follows:

$$
\begin{aligned}
& y_{t}=a_{1}+\sum_{i=1}^{k} \phi_{1 i} y_{t-i}+\sum_{i=1}^{k} \theta_{1 i} x_{t-i}+u_{1 t} \\
& x_{t}=a_{2}+\sum_{i=1}^{k} \phi_{2 i} y_{t-i}+\sum_{i=1}^{k} \theta_{2 i} x_{t-i}+u_{2 t}
\end{aligned}
$$

where equation (4) specifies the export price of country $y$ as a function of its own past price values up to $k$ lags, the past values of the export price of country $x$ up to $k$ lags and a white noise error term $\left(u_{1}\right)$. Equation (5) specifies the same explanatory variables for country $x$.

\section{Causality tests}

In the Granger sense, causality is the ability of past values of $x$ predicting the contemporaneous movements in $y$. If this holds, $x$ can be said to Granger-cause $y$. Within the field of price transmission, this can be seen as the ability of the past price movements of one market predicting the contemporaneous movements of another price. The Granger causality test is basically an autoregressive specification of $y$ where the past values of another variable, $x$, are added to the autoregressive equation. In other words, it tests whether the removal of the lags of $x$ from the autoregressive equation leads to a loss of information which explains the current movements in $y$. The Granger test is essentially a Wald test which restricts all of the lags of the explanatory variable we are interested in to zero within the autoregressive equation. For equations 4 and 5 the null and alternative hypotheses $\left(H_{0}\right.$ and $\left.H_{\mathrm{a}}\right)$ are as follows:

$$
\begin{aligned}
& H_{10}: \theta_{11}=\theta_{12}=\cdots=\theta_{1 k}=0 ; H_{1 a}: \text { At least one } \theta_{1} \text { is not zero } \\
& H_{20}: \phi_{21}=\phi_{22}=\cdots=\phi_{1 k}=0 ; H_{2 a}: \text { At least one } \phi_{2} \text { is not zero }
\end{aligned}
$$

In this example, one could infer that a rejection of $H_{10}$ and $H_{20}$ suggests there is bidirectional transmission between the export prices while failing to reject $H_{10}$ and $H_{20}$ 
would suggest there is no price transmission. Meanwhile, rejecting $H_{10}$ and not $H_{20}$ would suggest that prices only transmit unidirectionally from export price $x$ to export price $y$, while rejecting $H_{20}$ and not $H_{10}$ would suggest the opposite.

If the Granger causality tests are performed on the first-differences of the price series then the tests provide information on the relationship between the price changes and can be seen as short run price transmission since the long run information is taken out of the price series when they are first-differenced. There is, however, another causality test which can be performed even if the system of equations includes non-stationary processes. The Toda-Yamamoto causality test is similar to the Granger test but has the advantage of allowing non-stationary series to be included in the test procedure therefore the series do not need to be first-differenced. This means that the series contain their long-run information so the Toda-Yamamoto test can provide insight into price transmission which is not restricted to the short-run. The only preliminary information needed before performing the Toda-Yamamoto causality test is the maximum order of integration of the variables $\left(d_{\mathrm{m}}\right)$ included in the VAR system. Once the optimal number of lags $(k)$ is selected for the model, the VAR is specified as a $\operatorname{VAR}\left(k+d_{\mathrm{m}}\right)$. For instance, if the optimal number of lags is three and the maximum order of integration is one, the model is specified as a $\operatorname{VAR}(3+1)$.

The Toda-Yamamoto causality test then follows the same procedure as the Granger causality test where a Wald test is performed to restrict all of the lags of the selected explanatory variable up to $k$ to zero. Equation (4) would therefore be modified as follows:

$$
y_{t}=a_{3}+\sum_{i=1}^{k+d m} \phi_{3 i} y_{t-i}+\sum_{i=1}^{k+d m} \theta_{3 i} x_{t-i}+u_{3 t}
$$

The hypotheses of the Toda-Yamamoto test are as follows:

$$
H_{30}: \theta_{31}=\theta_{32}=\cdots=\theta_{3 k}=0 ; H_{3 a}: \text { At least one } \theta_{3} \text { is not zero }
$$

whereby the coefficients included in the test go up to $k$ and not $d_{m}$. The results can then be interpreted in the same way as the Granger causality results.

\section{Impulse response functions}

A weakness of the causality tests is that the values of the coefficients are difficult to interpret within the VAR system therefore these tests cannot tell us anything about the magnitude of the price transmission, only whether price transmission exists or not. Impulse response functions (IRF) are commonly used to assess what impact each of the variables included within the VAR system have on one another. It does this by assessing the error terms of the equations which it sees as shocks. IRFs simulate the effect a shock originating in one variable has on the other variables in the VAR system and is able to quantify its impact over proximate time periods. Cholesky factorization is used to identify where the shocks are coming from which is done using the recursive structure of the values of the variance-covariance matrix elements to select the restrictions and therefore identify the origin of the shocks. In other words, the assumption is made that the shocks from the reduced form equations simulate the structural shocks of the VAR system. 
A major issue with using the recursive structure for identifying the shocks is that the IRFs become sensitive to the ordering of the variables within the VAR system if the error terms are highly correlated. One way to get over this problem is by ordering the variables from the most exogenous to most endogenous variable within the system. However this requires in depth knowledge of the relationship between the variables. In the case of this study, it does not seem appropriate to leave it up to the researcher's a priori judgement on the exogeneity of the export prices as this is precisely what the study is attempting to test. A solution is to use the Generalised IRFs as these are not sensitive to the ordering of the variables, and are therefore used in this study. IRFs can simulate how one variable responds to a one standard deviation shock in its own stochastic process or any other variable within the VAR system over a designated number of time periods after the initial shock. IRFs can therefore provide information on the magnitude of price transmission as well as its persistence and direction. For this study, generalized IRFs will be simulated in the cases where export prices are found to Granger cause other export prices as they can provide further information to supplement the causality tests as to the extent of price transmission between international rice markets.

\section{Preliminary analysis of data}

The export prices of five major rice markets are used in this study which were taken from the Food and Agricultural Organisation's Global Information Early Warning System (GIEWS) database. The prices are measured in a common currency, namely monthly FOB export prices in nominal US dollars. The Thai and Vietnamese prices are the five per cent broken rice prices, the American price is the two to four per cent broken price, the Argentinean price is the ten per cent broken price, and the Pakistani price is the twenty five per cent broken price. The prices are therefore seen as representing the higher quality indica grades of rice apart from the Pakistani price. While the higher quality Pakistani price was not available, it is assumed that the higher quality Pakistan price closely follows price movements in the lower quality Pakistani price since this is the case for Thai and Vietnamese rice export prices. The Uruguayan export price is probably a more important rice price for South American markets than the Argentinean price, however, data was only available from 2006 which would have severely cut the available number of observations included in the study therefore the study assumes that Argentinean prices are related to Uruguayan price movements and are therefore suitable for the analysis. Indian export prices are also available; however, due to the Indian government's policy of temporal rice export bans there are many breaks in the price series therefore Indian prices cannot be included in the study.

Three unit root tests are used to provide insight into the stationarity of the export prices. The Augmented Dickey-Fuller (ADF) and Phillips-Perron (PP) tests are seen as the conventional unit root tests whereas the Zivot-Andrews (ZA) test is also included as this test considers the existence of a structural break in the time series. An advantage of the ZA test is that it endogenously determines the date of the structural break rather than leaving it up to the researcher's judgement to decide on the date. From observing Figure 1, the behavior of all five price movements suggests that there may have been a structural break in the time period 2007-2008. A priori knowledge of world rice prices would suggest this to be true as this period is often referred to as the 


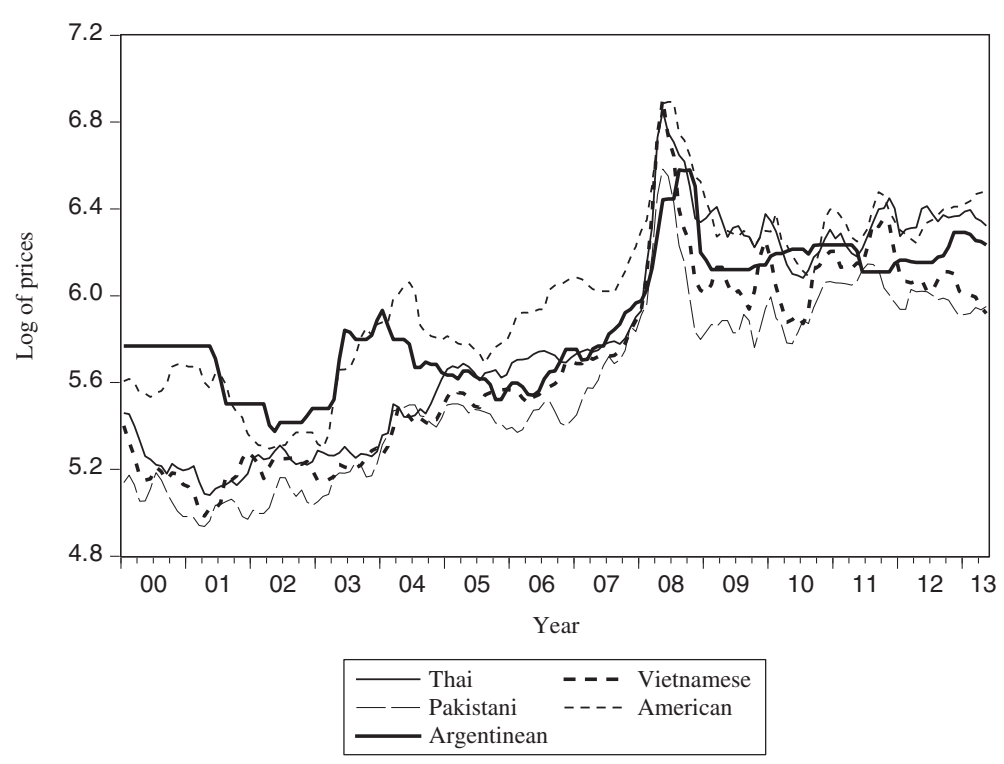

Figure 1 Monthly export prices of five major international markets: January 2000 to May 2013.

'food crisis' when international food commodity prices including rice increased to unprecedented levels.

According to the result of Table 1, the ADF give mixed results whereby evidence is found to suggest that the Asian rice prices are stationary while the American and Argentinean prices are I(1) non-stationary processes. On the other hand, the PP tests find all of the prices to be I(1) non-stationary processes. The ZA results, however, conform to the ADF results which find the three Asian prices to be stationary processes when considering the existence of a structural break while the American and Argentinean prices are non-stationary. Since the power of the conventional unit root test is lowered in the presence of a structural break (Perron, 1989) the study considers the ZA results to be the most suitable to follow. Furthermore, since both the ADF and PP results did not find any of the prices to have a higher order of integration than one, one is considered to be the maximum order of integration for the Toda-Yamamoto causality procedure.

\section{Results}

Two VAR models were specified. The first used the first-differences of the five export prices while the second contained the prices in their level form. Two VARs were

Table 1 Unit root tests ${ }^{a}$

\begin{tabular}{|c|c|c|c|c|c|c|}
\hline \multirow[t]{2}{*}{ Export Price } & \multicolumn{4}{|l|}{ Level } & \multicolumn{2}{|c|}{ First-difference } \\
\hline & $\overline{A D F}$ & PP & ZA & Structural break & $\overline{A D F}$ & PP \\
\hline Thailand 5\% & $-3.380^{*}$ & -2.884 & $-6.552^{* * *}$ & $2008 \mathrm{~m} 02$ & $-7.556^{* * *}$ & $-7.264^{* * *}$ \\
\hline Vietnam 5\% & $-3.804^{* *}$ & -2.796 & $-6.017^{* * *}$ & 2008 m02 & $-7.251^{* * *}$ & $-5.923^{* * *}$ \\
\hline Pakistan 25\% & $-3.794^{* *}$ & -2.813 & $-5.692^{* * *}$ & 2007 m09 & $-7.123^{* * *}$ & $-7.096^{* * *}$ \\
\hline U.S 2-4\% & -3.102 & -2.589 & -4.141 & 2007 m09 & $-6.984^{* * *}$ & $-7.025^{* * *}$ \\
\hline Argentina 10\% & -2.808 & -2.422 & -4.001 & 2007 m07 & $-7.818^{* * *}$ & $-7.707^{* * *}$ \\
\hline
\end{tabular}

${ }^{a}$ The time period of the price series is from January 2000 to May 2013. The prices are in their logarithmic transformations. A trend and intercept were included in the unit root tests. ${ }^{*},{ }^{* *},{ }^{* * *}$, signify a ten, five, and one percent level of significance of the unit root tests. 
needed so Granger causality tests could be made using the first VAR system and could provide information on the short run price transmission between international rice markets since this system uses the price changes of the export prices. Meanwhile, the second VAR system was used for the Toda-Yamamoto causality procedure which can provide insight into price transmission which was not restricted to the short term.

The Granger causality results are in Table 2 . They suggest that short run price transmission exists across the Asian markets with bidirectional price transmission between Thailand and Vietnam as well as between Pakistan and Vietnam. Price transmission occurs in the short run from Pakistan to Thailand; however, it is not bidirectional. The Granger test did not find evidence to suggest that Thai prices transmitted to Pakistani prices in the short run.

Surprisingly, no short run transmission was found between the US and any of the Asian markets which suggests that the former is completely unrelated to the latter markets even though their rice markets are of a similar grade and they compete in some of the same markets in Africa and parts of Latin America. The only market American price movements responded to in the short run was Argentina; however the price transmission was not bidirectional. On the other hand, the Argentinean market was found to be related to two of the Asian markets, namely Vietnam and Pakistan. However, Argentinean prices did not transmit over to any of the Asian markets, possibly because the former is dwarfed by the latter markets.

Overall, the most price related markets were Vietnam and Pakistan as they both transmitted their price movements to all of the other markets apart from the US. In addition, Vietnam was the only market to respond to the price movements of all of the other markets except for the US which would suggest that Vietnam is the most suitable reference price for international rice prices amongst the five prices, in the short run at least.

According to the Toda-Yamamoto causality results, price transmission which considers both the short and long-run price movements is similar amongst the Asian markets vis-à-vis short run price transmission which was tested using the Granger procedure. What is interesting is that even considering the long run information in the

Table 2 Granger causality tests ${ }^{b}$

\begin{tabular}{|c|c|c|c|c|c|}
\hline Export prices & $\rightarrow$ Thailand & $\rightarrow$ Vietnam & $\rightarrow$ Pakistan & $\rightarrow$ U.S. & $\rightarrow$ Argentina \\
\hline \multirow[t]{2}{*}{ Thailand $\rightarrow$} & $x$ & $20.494^{* * *}$ & 4.265 & 3.086 & 1.776 \\
\hline & & $(0.001)$ & $(0.385)$ & $(0.687)$ & $(0.879)$ \\
\hline \multirow[t]{2}{*}{ Vietnam $\rightarrow$} & $17.269^{* * *}$ & $x$ & $19.656^{* * *}$ & 8.238 & $14.770^{* *}$ \\
\hline & $(0.004)$ & & $(0.001)$ & $(0.144)$ & $(0.012)$ \\
\hline \multirow[t]{2}{*}{ Pakistan $\rightarrow$} & $12.952^{* *}$ & $10.057^{*}$ & $x$ & 7.189 & $11.127^{* *}$ \\
\hline & $(0.024)$ & $(0.074)$ & & $(0.207)$ & $(0.049)$ \\
\hline \multirow[t]{2}{*}{ U.S. $\rightarrow$} & 1.248 & 1.483 & 2.108 & $x$ & 4.382 \\
\hline & $(0.940)$ & $(0.915)$ & $(0.834)$ & & $(0.496)$ \\
\hline \multirow[t]{2}{*}{ Argentina $\rightarrow$} & 4.013 & 3.118 & 5.809 & $14.838^{* *}$ & $x$ \\
\hline & $(0.548)$ & $(0.682)$ & $(0.325)$ & $(0.011)$ & \\
\hline
\end{tabular}

b The figures in the boxes are the Wald test statistics and the $p$-values are in brackets. ${ }^{*}, * *{ }^{* * *}$, signify a ten, five, and one percent level of significance of the Granger causality tests. The arrows indicate the direction of price transmission. According to the Schwarz Information Criterion, the optimal number of lags is one, however five lags are required in order to ensure the error terms are not serially correlated therefore a VAR(5) model is specified. There are 156 observations. 
price series, the Toda-Yamamoto results suggest that Thai prices do not transmit over to Pakistani prices. Having said that, overall, the results of both causality procedures suggest that the Asian export markets are affected and respond to each others' price movements.

American prices do not transmit over to any of the other export prices even when considering the long run information of the price series, however, American prices do respond to the Thai and Vietnamese prices as well as Argentinean prices according to the Toda-Yamamoto results. This suggests that Asian and US rice prices have been related over the past decade. However, the Toda-Yamamoto and Granger test results suggest that Asian markets do not respond to North and South American rice prices. Asian rice prices may therefore be seen as leading the price movements of international rice prices for other regions which is understandable since Asian rice exports make up the bulk of world rice trade.

In line with the Granger results, the Toda-Yamamoto tests suggest that Vietnam has the most far reaching effect on other international rice prices as the results in Table 3 suggest that Vietnamese prices transmit to all four of the other prices included in the analysis. On the other hand, Thai prices only transmit over to Vietnamese and American prices. The causality results therefore suggest that the Vietnamese price is the most suitable reference price for international rice prices for the higher quality indica market, at least.

Generalized impulse response functions were simulated to interpret the magnitude of price transmission in the cases where price transmission was identified by the Granger causality tests in the first specified VAR system. Figure 2 illustrates the impact of shocks transmitting over to other export markets. The Granger causality tests identified that bidirectional price transmission occurred between Vietnam and Thailand, and Vietnam and Pakistan. The IRFs suggest that the magnitude of the price transmission is fairly symmetrical. However, shocks originating in the Vietnamese prices which transmit over to the Thai and Pakistani prices persist slightly longer than shocks originating in the latter two countries and transmitting to the Vietnamese market. Even though the shocks represent the short run effects since it was the price changes which were used to simulate the IRFs, the magnitude of Vietnamese shocks are statistically

Table 3 Toda-Yamamoto causality tests ${ }^{d}$

\begin{tabular}{lccccc}
\hline Export prices & $\rightarrow$ Thailand & $\rightarrow$ Vietnam & $\rightarrow$ Pakistan & $\rightarrow$ U.S. & $\rightarrow$ Argentina \\
\hline Thailand $\rightarrow$ & $x$ & $28.277^{* * *}$ & 9.522 & $11.105^{*}$ & 2.322 \\
Vietnam $\rightarrow$ & $(<0.001)$ & $(0.146)$ & $(0.085)$ & $(0.888)$ \\
& $18.652^{* * *}$ & $x$ & $18.630^{* * *}$ & $12.127^{*}$ & $15.591^{* *}$ \\
Pakistan $\rightarrow$ & $(0.005)$ & & $(0.005)$ & $(0.059)$ & $(0.016)$ \\
& $13.818^{* *}$ & $17.082^{* * *}$ & $\times$ & 9.047 & $(0.784$ \\
U.S. $\rightarrow$ & $(0.032)$ & $(0.009)$ & & $(0.171)$ & 3.555 \\
Argentina $\rightarrow$ & 1.470 & 0.626 & 2.184 & $(0.902)$ & $(0.737)$ \\
& $(0.962)$ & $(0.996)$ & 5.027 & $15.572^{* *}$ & $\times$ \\
\end{tabular}

${ }^{\mathrm{d}}$ According to the Schwarz Information Criterion, the optimal number of lags is two, however six lags are required in order to ensure the error terms are not serially correlated therefore a VAR $(6+1)$ model is specified. There are 154 observations. ${ }^{*},{ }^{* *},{ }^{* *}$, signify a ten, five, and one percent level of significance for the Toda-Yamamoto causality tests. 


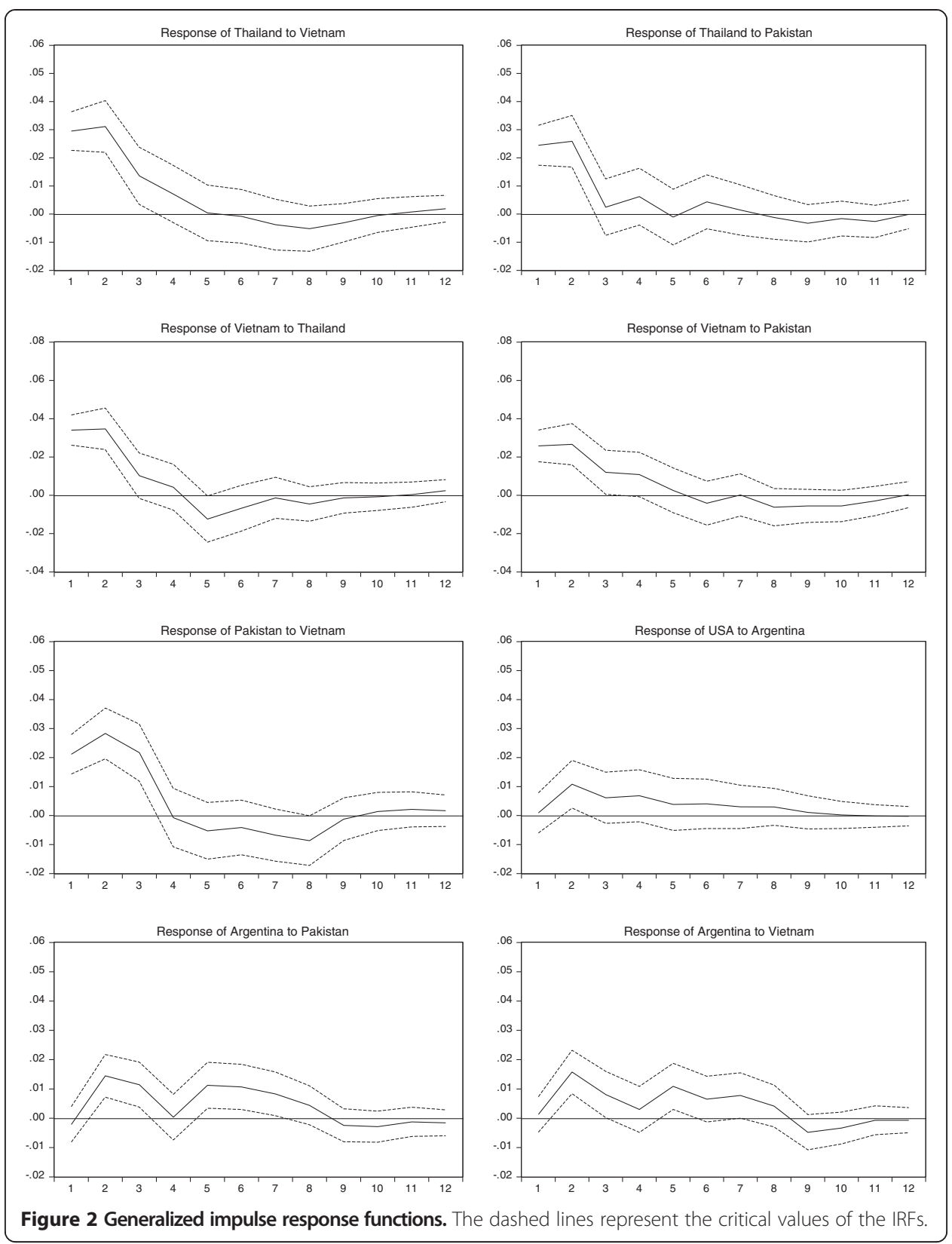

significant for three months in the other two Asian markets whereas Thai and Pakistani shocks in the Vietnamese market are statistically significant for two months.

Pakistani shocks in the Thai market are roughly as significant in magnitude as Vietnamese shocks, however they only persist for two months, statistically speaking. Although the causality tests found Argentinean prices to transmit over to US prices, the IRF graph shows that its magnitude is barely significant for the second month after the original shock. The last two IRF graphs illustrate the impact of Vietnamese and Pakistani prices on the Argentinean price. What they show is that while the magnitude of this transmission is less than a third of the peak of price transmission between the Asian markets, it is more persistent. For instance, the magnitude of Pakistani and Vietnamese shocks are statistically significant for the second, third, fifth and sixth months 
and second and fifth months after the original shock in the Argentinean market, respectively.

Perhaps the main finding from the IRFs is that while price transmission occurs between rice markets in Asia and the Americas, the price transmission between Asian markets is far greater than price transmission across the continents. This can be explained by the fact that competition between Asian markets is stronger as they are competing in most of the same markets.

\section{Discussion and conclusions}

The paper set out to examine the extent of price relations between major rice exporting nations using causality tests and IRFs to test for price transmission. It is generally perceived in the literature that international rice markets have a low level of substitution which fragments the market and thins out an already thin world rice market. One would therefore expect the prices of different rice export markets to be unrelated.

Both causality tests and the IRFs suggest that Asian rice export markets are related to one another. One would therefore not infer that there is a low level of substitution between these markets which conforms to Ghoshray's (2008) findings that Thai and Vietnamese rice export prices are integrated, albeit asymmetrically. In fact, this study's results would suggest that they are to some extent competitive which one should expect since they compete against each other in many of the same markets.

Although the Granger causality tests reported that Asian and US rice prices are not related in the short term, US prices have, at least over the last decade, responded to price movements of major Asian export markets, according to the Toda-Yamamoto causality tests which were not restricted to using the short run price information. The same results were found for Argentinean rice prices which suggest that the South American rice prices are related to Asian rice prices. While these findings may conform to Dawe's (2008) conclusion, in the short run, that US and Asian rice prices in contemporary times are unrelated, the fact that the Toda-Yamamoto causality results found Asian prices to transmit over to US prices raises some doubt over the view that US and Asian rice markets function as two separate commodity markets. Dawe (2008) is correct that the US does not export indica rice to Asian markets but the US does compete with Asian exporters in some African and Latin American markets, which suggests that there should be some price relations between American and Asian rice export markets.

What the causality tests show is that Asian rice markets are clearly acting as price leaders for the other export markets since the direction of price transmission is from the former and to the latter. This is understandable since the Asian markets are much larger rice producers and dominate international rice trade. The results also show that Vietnamese prices affect the price movements of all of the other export markets, which is not true for Thai prices. This is not necessary contrary to what Ghoshray (2008) reported, namely that between Thailand and Vietnam, the former acts as a price leader. This study's results show that price transmission between these two markets is bidirectional and that the impact according to the IRFs is almost symmetrical. I therefore find no clear price leader between the two markets. However, since the Vietnamese price exhibits price relations between all of the other rice export markets included in this study, which cannot be said for the Thai price, it seems sensible to conclude that the Vietnamese price is a more suitable reference price for international rice prices than the Thai price. 
The results of the study imply that domestic and border policies in major rice exporting countries do not inhibit price transmission between many of the rice export markets covered in this study. It is often argued that rice exporting nations distort their export price movements and therefore their trade behavior in order to isolate their domestic rice prices from world price fluctuations. In the case of Thailand, John (2013) reported that while the rice pledging program affects price transmission between Thailand's domestic and export rice markets, price transmission takes place bidirectionally. However, the impact of price transmission from the export market to the domestic market is reduced in the short run but then remains rather persistent.

The impact of border and domestic policy on price transmission between markets depends on the type of policy tool used. Intervention mechanisms such as floor prices could lead to domestic prices being completely unrelated to world prices or being related in a non linear way (Rapsomanikis, Hallam, and Conforti, 2003). Price transmission will only take place if the world price is above the domestic floor price. The floor price will act as a threshold therefore the existence of a floor price may cause price transmission to be asymmetric. Despite the use of minimum rice export prices in Thailand and Vietnam, which act as floor prices, the study's results found these two markets to be related to each other as well as with other markets. This was despite the fact that the methods used in this study did not consider the presence of asymmetric price relationships. This can be explained by the fact that Thai and Vietnamese authorities regularly adjust their minimum export prices in order to keep their rice exports competitive in world markets when they want to release rice stocks. This is precisely what has happened in Thailand in 2013 as the government has continued to lower their minimum export prices in order to make their rice export prices more competitive. While previously, Thailand purposely kept its minimum export prices above world prices, as the cost of the pledging program has built up and surpassed the $\$ 16$ billion allocated to it, the government has been trying to release the rice stocks it accrued from the rice farmers who participated in the pledging program during 2011 and 2012 in order to recoup part of the cost of the rice pledging program which has cost $\$ 8$ billion excluding administrative costs (USDA, 2013).

As previously mentioned, like Thailand, Vietnam uses minimum export prices. However, it does not subsidize the price the farmer receives for their rice which is what the pledging program essentially does. The absence of a program similar to the pledging program in Vietnam may explain why Vietnamese rice export prices are more related to other export rice markets than Thai prices according to the study's results. This is because such a policy would require the government to distort trade volumes through holding on to vast sums of rice in public stock holds.

It is unsurprising that Pakistan responds to price movements in other Asian rice markets as it liberalized its rice industry in the later 1990s. US price movements do not transmit over to the other four export markets. This seems to be a rather puzzling finding at first sight since although it is by no means the largest rice exporter; it is still one of the top rice exporters in the world. This may be due to the fact that a substantial amount of rice the US exports is not indica rice but japonica rice. Despite the lack of price transmission from US rice prices to other export markets, US prices do react to price movements in the other major rice export markets according to the TodaYamamoto results. There is little reason to doubt these results since the US does not 
distort its export prices. However, the US heavily subsidizes its rice farmers which push world rice prices down by four to six percent (Griswold, 2006). The US would export far less if not any rice if it was not for it subsidizing its rice farmers.

India was not included in the study; however it is important to mention the impact of Indian domestic policy on the price relations of its rice export market with other international rice markets. Despite being the top rice exporter in recent years, India's trade patterns in rice as well as many other food commodities can be erratic as international markets are seen as a way of offloading surplus stock rather than an opportunity for earning foreign exchange. India provides its farmers with support prices so Indian farmers make their business decisions based on these prices rather than international prices. Minimum export prices are used by India and the government also at times uses export bans in order to secure rice supplies for domestic consumption. Such policies, of course, completely block any price transmission from other export prices to India's prices. It seems intuitive; however, that in periods like what India has experienced recently when it has surplus rice supplies and decides to participate in world rice trade, price transmission occurs as the government drops the minimum export price so their rice prices are competitive with international prices. India's interventionist policies which impede price transmission are likely to remain especially with the implementation of the National Food Security Act passed in parliament in 2013 and involves allocating rice and other grain rations to over 800 million of its inhabitants.

The world rice market may be a thin market but the study's results would suggest that it is not as fragmented as some of the literature proposes, at least when one considers indica rice markets which make up the bulk of world rice production and trade. This is especially the case for Asian rice export markets. An implication of this is that large Asian rice exporting nations have the ability to destabilize the international rice market. In one sense, the study's results demonstrate that governments of major rice export markets do not generally distort their export prices to the extent that these prices remain isolated from other export rice prices. On the other hand, due to the fact that it is such as thin market, the price distortions of one major rice exporting country has the ability to destabilize the international rice market as a whole due to the existence of price transmission between these markets. The unprecedented rise in international rice prices across the world which peaked in 2008 is a striking example which has been argued that the actions of India banning non-basmati rice exports was one of the main causes which initiated the pricing frenzy (Headey, 2011).

To address the concerns of many low income rice import dependent countries, a global rice reserve has been proposed to help stabilize international rice prices during volatile periods (Gilbert, 2013). Since this study would suggest that international rice markets do react to each others' price movements, particularly in Asia, it may seen appropriate that any negotiations of forming such a global rice reserve should involve the two largest rice producers and stockholders, China and India, whereby these countries could play a major role in stabilizing thin world rice markets rather than being a source of volatility.

\section{Endnotes}

${ }^{\text {a }}$ From observations of annual rice trade data from the UN COMTRADE database.

${ }^{\mathrm{b}}$ If $c=0$ then the prices across the markets would be identical once the prices had been converted into a common currency (Rapsomanikis, Hallam, and Conforti, 2003). 


\section{Competing interests}

The author declare that he have no competing interests.

\section{Acknowledgements}

I appreciate the reviews and comments I received from the two anonymous reviewers.

\section{Received: 29 October 2013 Accepted: 14 December 2013} Published: 03 Jan 2014

\section{References}

Anderson JD, Hudson D, Harri A, Turner S (2007) A new taxonomy of thin markets. Paper presented at the annual meeting of the Southern Agricultural Economics Association, Mobile, Alabama. 4-7 February 2007

Barrett CB, Li JR (2002) Distinguishing between equilibrium and integration in spatial market analysis. Am J Agric Econ 84(2):292-307

Chan LY (1997) Price instability in the international rice market: its impact on production and farm prices. Dev Pol Rev 15:251-276

Chand R (2006) International trade, food security and the response to the WTO in South Asian countries: discussion paper No. 2006/124. UN University-World Institute for Development Economics Research (UNU-WIDER), Helsinki, Finland

Cramer G, Wailes EJ, Shui S (1993) Impacts of liberalizing trade in the world rice market. Am J Agric Econ 75:219-226

Conforti P (2004) Price transmission in selected agricultural markets: FAO Commodity and Trade Policy Research working paper No. 7. Basic Foodstuffs Service, Commodities and Trade Division, Food and Agricultural Organization, Rome

Dawe D (2008) Have recent increases in international cereal prices been transmitted to domestic economies? The experience of seven large Asian countries. ESA working paper No. 08-03, Agricultural Development Economics Division, The Food and Agriculture Organization of the United Nations, Rome

Dawe D, Slayton T (2011) The world rice market in 2007-08. In: Prakash A (ed) Safeguarding food security in volatile global markets. Food and Agriculture Organization of the United Nations, Rome, pp 171-182

Demeke M, Pangrazio G, Maetz M (2011) Country responses to turmoil in global food markets. In: Prakash A (ed) Safeguarding food security in volatile global markets. Food and Agriculture Organization of the United Nations, Rome, pp 183-210

Dorosh PA (2009) Price stabilization, international trade and national cereal stocks: world price shocks and policy response in South Asia. Food Secur 1:137-149

Falcon W, Monke E (1980) International trade in rice. Food Res Inst Stud 17(3):279-306

Gibson J (1994) Rice self-sufficiency in Papua New Guinea. Rev Mark Agric Econ 62(1):63-77

Gilbert CL (2011) Grains price pass-through, 2005-09. In: Prakash A (ed) Safeguarding food security in volatile global markets. Food and Agriculture Organization of the United Nations, Rome, pp 127-148

Gilbert CL (2013) International agreements to manage food price volatility. Global Food Secur 1:134-142

Gilbert CL, Morgan CW (2010) Food price volatility. Philos Trans R Soc 365(1554):3023-3034

Ghoshray A (2011) Underlying trends and price transmission of agricultural commodities: ADB Economics working paper series No. 257. Asian Development Bank, Metro Manila, Philippines

Ghoshray A (2008) Asymmetric adjustment of rice export prices: the case of Thailand and Vietnam. Int J Appl Econ 5 (2):80-91

Griswold D (2006) Grain drain: the hidden cost of U.S. rice subsidies No. 25. Center for Trade Policy Studies, Cato Institute, Washington, DC

Headey D (2011) Rethinking the global food crisis: the role of trade shocks. Food Policy 36:136-146

Jayne TS (1993) Sources and effects of instability in the world rice market. MSU International Development Paper No. 13. Michigan State University, East Lansing, Michigan

John A (2013) Price relations between export and domestic rice markets in Thailand. Food Policy 42:48-57

Nielsen CP (2003) Vietnam's rice policy: recent reforms and future opportunities. Asian Eco J 17:1-26

Perron P (1989) The great crash, the oil price shock and the unit root hypothesis. Econometrica 57:1361-1401

Petzel TE, Monke EA (1980) The integration of the international rice market. Food Res Inst Stud 17(3):307-326

Rapsomanikis G (2011) Price transmission and volatility spillovers in food markets. In: Prakash A (ed) Safeguarding food security in volatile global markets. Food and Agriculture Organization of the United Nations, Rome, pp 149-168

Rapsomanikis G, Hallam D, Conforti P (2003) Market integration and price transmission in selected food and cash crop markets of developing countries: review and applications. In: Commodity market review 2003-2004. Commodities Trade Division, Food and Agriculture Organization of the United Nations, Rome, pp 51-75

Rastegari-Henneberry S (1985) The world rice market: Giannini Foundation Information Series No. 85-2. University of California Davis, Davis, California

Seck PA, Tollens E, Wopereis MCS, Diagne A, Bamba I (2010) Rising trends and variability of rice prices: threats and opportunities for sub-Saharan Africa. Food Policy 35:403-411

Siamwalla A, Haykin S (1983) The world rice market: structure, conduct and performance. Research: Report 39: International Food Policy Research Institute, Washington, DC

Stage O, Rekve P (1998) Food security and food self-sufficiency: the economic strategies of peasants in Eastern Ethiopia. Euro J Dev Res 10(1):189-200

Timmer PC (2010) Management of rice reserve stocks in Asia: analytical issues and country experience. In: Commodity market review 2009-2010. Food and Agriculture Organization of the United Nations, Rome, pp $88-120$

Tomek WG, Robinson KL (1990) Agricultural Product Prices, 3rd edition. Cornell University Press, Ithaca, NY

USDA (2013) GAIN report, Thailand: grain and feed update. GAIN report number: TH3111, Bangkok 
Wailes EJ (2002) Trade liberalization in rice. In: Kennedy PL (ed) Agricultural trade policies in the new millennium. Haworth Press, New York

Wailes EJ (2005) Rice: global trade, protectionist policies, and the impact of trade liberalization. In: Aksoy MA, Beghin JC (ed) Global agricultural trade and developing countries. The World Bank, Washington, DC, pp $177-194$

Xuifang D, Dwyer W (2008) Rethinking China's domestic agriculture support measures under WTO protocols. J Asia Pacific Eco 13:82-98

10.1186/2193-7532-2-1

Cite this article as: John: Price relations between international rice markets. Agricultural and Food Economics 2014, 2:1

Submit your manuscript to a SpringerOpen ${ }^{\circ}$ journal and benefit from:

- Convenient online submission

- Rigorous peer review

- Immediate publication on acceptance

- Open access: articles freely available online

- High visibility within the field

- Retaining the copyright to your article

Submit your next manuscript at $\gg$ springeropen.com 